InnOvaciOnes de NegOciOs 17(33): 74-85

(C) 2020 UANL, Impreso en México (ISSN: 2007-1191)

Recepción: 22 Octubre 2019 Aceptación: 10 Enero 2020

\title{
Sunk Costs Fallacy in Subprime Bubble (Falacia de costos hundidos en burbuja de alto riesgo)
}

\author{
Eduardo Velázquez Juárez \\ Universidad Autónoma de Querétaro \\ vjlalo@gmail.com
}

\begin{abstract}
Financial Bubbles have been interesting for many people, especially in the academic area. It is necessary to understand them with the thoughtfulness they deserve, due to their potential to cause social, economic and political disruptions. In this paper, is reviewed the subprime bubble from a documental approach, and it is enriched with the contributions of the behavioral finances, specifically with the role of sunk costs fallacy in the behavior of housing mortgages instead of the stock investors, as they are usually studied in several types of researches. It is suggested that sunk cost fallacy may provide an additional and important point of view to understand this financial bubble from a parallel market point of view, because this fallacy could be the reason of holding mortgages that eventually became impossible to get paid, which was supported with the fact of relaxation in credit policy and unethical bank practices. Finally, the main consequences and chances experienced after the bubble are discussed, putting into consideration to explore this behavior with further researches in housing investors.
\end{abstract}

Keywords: Bubble, Financial, Subprime, Sunk costs fallacy

JEL: G41, D140, D91.

Resumen: Las burbujas financieras han sido de interés para muchas personas, especialmente en el área académica. Es necesario comprenderlas con la seriedad que requieren debido a su capacidad potencial de causar disrupciones sociales, económicas y políticas. En este artículo se aborda la burbuja financiera 'Subprime' desde una aproximación documental y es enriquecida con las contribuciones de las finanzas conductuales, específicamente con el papel de la falacia de los costos hundidos como una propuesta para estudiar el comportamiento de los deudores de hipotecas, en vez de estudiar a los inversionistas como es usual en investigaciones similares. En esta investigación se sugiere que la falacia de los costos hundidos puede proveer un punto de vista adicional e importante para entender esta burbuja financiera, desde un punto de vista paralelo al mercado accionario, ya que este comportamiento puede incorporar la razón por la cual los deudores alcanzaron el punto de impago de sus hipotecas, lo cual fue apoyado por una política de crédito laxa y carencia de ética en las prácticas bancarias. Por último, se discuten las

\section{Sunk Costs Fallacy in Subprime Bubble}


consecuencias y cambios experimentados después de la burbuja, poniendo en consideración la exploración del comportamiento para futuras investigaciones.

Palabras clave: Burbuja, Financiera, Falacia de Costos Hundidos, Subprime.

\section{Introduction}

Along with Financial Bubbles history, there are a large number of experiences and academic explanations that involve people's sentiments and feelings. Since Tulipmania to the current formation of a possible bubble with Bitcoins around the world, Financial Bubbles have been part of the contemporary world's life and it must be considered with enough thoughtfulness that it demands. As a research background of this article, contributions given by Brueckner, Calem, \& Nakamura (2011) who studied the relations between pricing expectations in housing market and the extent of lending, their main findings were that bubble conditions enhanced price expectations, which increased willingness to extend loans to riskier borrowers. Also, researches like Namouri, Jawadi, Ftiti, \& Hachicha (2018) and Talbi \& Halima (2019) studied financial bubbles from behavioral finances, considering investor sentiment approach to provide specific explanations to Subprime Bubble. Agarwal, Green, Rosenblatt, \& Yao (2015) provided similar opinions about how sunk cost fallacy has an important role in debt defaulting showing the relations between initial payments and default hazard. As it is reviewed in different researches, financial bubbles and behavioral finances are understood as a major concern in financial markets, but they lack of giving alternative perspectives rather than market structure and investor sentiment. For this reason, this study is justified because it incorporates sunk costs fallacy as an additional contribution to the state of art by putting together both considerations in Subprime Bubble in different actors rather than investors, through this theoretical approach, financial studies provide an alternative to understand how bubbles are affected for a non-rational bias, fulfilling a more complex perspective.

In this paper, the main objective is intended to provide an additional point of view which can help to give alternative explanations to the rise and development of the subprime bubble experienced in the mid-2000s, according to the behavioral finances, specifically using sunk cost fallacy that experienced mortgage debtors and CDO's and ABS investors.

\section{Velázquez Juárez, E.}


This paper is structured in the next way. Firstly, in the introduction the main objective and justification of this article are shown, and it also includes the previous scenario to bubble development. Other studies are considered for explaining different approaches for the bubble development, as well. This chapter explains the general context that created the bubble and its main reasons; the price development and the main actors. These elements guide the main idea of financial bubbles. Then, in the theoretical framework, it is shown the main interest of this chapter that is explaining the role of the sunk cost fallacy in the development of the bubble and how it may play a decisive role in bubble development. The data description of the Composite-10 CSXR index is used for this approach, because it incorporates the change in prices of a single-family house, over the same period of time in different years; it includes the 10 metropolitan most important areas in the United States, considering that this article is based in a documental methodology. Finally, the main consequences of the bubble and how it affected people's lives around the world, as well as the main socio-structural transformations according to the fallacy are shown in the results. As final discussions, this paper provides additional aspects to consider, regarding how can sunk cost fallacy affect the creation and development of a bubble. Some recommendations for further studies through this perspective are shown in this article as well.

\section{Theoretical Framework}

\section{The Subprime Bubble and the Sunk Costs Fallacy}

The Suprime Bubble is widely recognized to be one of the worst disruptions in financial markets history. It was a set of several events, conditions and legal situations that led to the late-2000's to a large crisis due to a rise in subprime segment mortgages in the U.S. housing market and presence of delinquencies and foreclosures that ended as a decline of securities backed by said mortgages, which implied a vortex that affected several sectors in worldwide economy and financial markets (Demmler, 2017).

Sunk cost, in the other hand, refers specifically to a cost that cannot be recovered, in this way, it has no effects in the future payments that will be received and has no role into a rational decision making (Augenblick, 2016). In this context, sunk cost fallacy is a quite regular phenomenon in people's

\section{Sunk Costs Fallacy in Subprime Bubble}


life, it is experienced in a large number of life experiences such as common purchases, emotional relationships, investments, business and career decisions (Krämer, 2017). It functions as follows, it is a cognitive bias that transform the way people make future decisions based in time, effort and money spent on a specific activity that does not present the expected results or payments, forcing people to consider abort the current activity to start another one, but anchored to it due to the loss feeling, forcing it, once again to make inconvenient and irrational decisions (Haita-Falah, 2017). This aspect will be important to understand the way mortgage debtor became sentimentally anchored to their houses. In this paper, it is relevant to put into consideration for further researches what would happen if housing investor could transfer their original mortgage debt to another debtor with the better financial condition (Doody, 2017).

To explain the bubble development it is necessary to present the previous and general phenomenon context, so it requires explaining the main economic sector that grew along with the bubble and the main changes in the housing market and innovations in financial markets, without appropriate legal framework. In the United States, mortgage loans are classified as Prime or Subprime depending on their credit risk, which means the probability of default on the loan (Foote \& Willen, 2016a). Naturally, Subprime interest rates are higher than Prime rates, reflecting their own credit risk in money cost and might drive people to miss a loan payment. To avoid it, low creditworthiness people require spending additional time, money and effort to complete the payment for subprime debt rather than prime debtors, this particular aspect centers its attention on this paper as the Subprime mortgage segment grew due to massive credit lending by U.S. banks to high-risk borrowers.

An important factor that played in the asset price bubble was the innovations made in financial instruments. By all means, these innovations brought over with them new structural changes in portfolio building and legal implications. With the repeal of the Glass-Steagall Act, banks were allowed to sell their credits to another underwriter, starting over a new process called securitization. In this process, the portfolio construction was designed considering mortgages, loans, corporate bonds or other receivables, incorporating a whole new product called Asset Bank Securities (ABS) and sell them in financial markets, allowing other investors to acquire them. It

\section{Velázquez Juárez, E.}


implied a new world of advantages in financial matter, as they are transferring risk from the bank to other institutions and spreading participants in the market, it brought as result higher income for banks at a lower cost and lower mortgages fees, bringing benefits to corporate and private clients (Demmler, 2017).

The main disadvantage in this innovation though, is that securitization brings moral hazard because risk bearing is not aligned with loan making and credit monitoring. This point gains special importance for this paper, because it incentives people to apply for new credits even when their financial situation is not in plenty sanity, requiring them additional effort for giving mortgage monthly paying

In this paper, it is important to specify that the US banking sector started securitization under a new model that in a disruptive way changed the way of doing business in the housing market. In this way banks packed mortgages into structured products, this was made under originate-todistribute process which particular way to structure portfolios consist in stratify products according to its own risk and return in three different categories: Senior tranche (Low risk, low return), Mezzanine (Mid-risk, mid-return), and Equity (High risk, high return) according to a waterfall principle that allows each tranche investor get paid as long as they cover their risk-return relationship. Firstly, paying to the Senior category and at last to the Equity category (Demmler, 2017).

However, the problem came out when Rating Agencies did not standardize guidelines and patterns to classify and evaluate ABS, they lacked information related to specific mortgagers- even when they designed $A B S$ in team with the banks- giving wrong results and scores and questioning their true quality of rating scores (Brunnermeier \& Schnabel, 2015; Markham, 2015).

There are specific factors that impulse Subprime Bubble to grow in the way it did, for example: low inflation rates and strong economic structural situation in the U.S.; expansive monetary policy as a reaction of the crash of the New Economy Bubble; high level of liquidity in the financial markets; attractive and new instruments for investors bringing overconfidence and lower sense of risk of the participants; and huge expansion in mortgage finance in subprime population, point which will be specified later (Markham, 2015).

\section{Sunk Costs Fallacy in Subprime Bubble}


The U.S housing bubble started with a massive expansion of financing in mortgages in the subprime segment. According to Shiller (2012), the segment raised from $6 \%$ to $15 \%$ in less than five years. The main mortgage used in the banking sector was the 2/28 Adjustable Rate Mortgage that worked in a scheme in which the borrower receives for two initial years a fixed rate, which eventually will change to a variable one for the next 28 years of the credit.

Inside the expansion of the subprime bubble, presents several reasons that made it grow accelerated and decontrolled in financial markets. As long as $A B S$ took away risk from banks and transferred it to other investors who were not aware of what kind of assets that shaped their investment portfolio and how risky they were (Hull, 2009). With the risk transferring, banks were much more lax with credit policy and less exigent housing foreclosures, causing that liar loaners come out and started to apply for credits using false information into the application form, previously knowing that this information will not be strictly checked by the banks, generating a whole new, massive and uncontrollable mass of credit applicants and new borrowers that started to invest time, money and effort to pay and cover their mortgage requirements, even though their credit histories and income levels would not be enough to cover the mortgage fee (Brueckner et al., 2011).

The bubble got stronger because banks started to give low-interest rates as an anchor for the rising demand for their products and it became attractive for borrowers as long as rates were in an interval of $1-2 \%$ p.a. to $6 \%$ p.a. until it becomes a variable scheme. This implies that housing borrowers have been paying their credit at least for two years, meanwhile financial bubble kept growing up, until the point in which interest rate reset came out and with higher demands -supported with the rise of interest rates due to the reversal FED's monetary policy- and making them regret about their credit decisions when they had to pay higher financial cost after the reset. This situation took people to default credit circumstances, payment shock and a particular sentiment that they should keep their mortgage after the 2-years of mortgage payments, effort and time spent on it (Demmler, 2017). 


\section{Methodology}

At this point, it is important to consider that the main interest of this paper is to provide a new perspective of how the behavioral finances act to support the growth of the financial bubble, for this reason this documental research, which is based in a review of different papers and documents is developed. It helps to support new ideas about understanding financial bubbles (León, 2017).

Documental methodology is based on recollection and validating information through several academic sources that will conduct the analysis and interpretation of different documents, as previous researches, books, and any other document that could be helpful to drive any ideas to give response to the main objective of this research (Bernal, 2010; Cazau, 2006; Galeano, 2012; Muñoz, 2015).

\section{Results}

The sunk cost fallacy is present in people's lives, and housing investors are not the exception. Considering that housing mortgagers have been paying at least for the initial 2-year fixed-rate scheme, it implies resources spent on it, while the bubble kept growing up, and expenditures made on the credit have created a sentimental link between the owner and the efforts invested in mortgage, which are sunk costs and are not relevant for future considerations in decision making.

In this way, housing mortgagers lack awareness about sunk cost fallacy and herding behavior, which led people to make decisions standing on holding as much as they could their housing mortgage.

In Figure 1. is shown the development of the bubble according to with the Composite-10 CSXR housing index that intends to show how housing princes increase, until they reach the peak of the bubble with increasing levels of $93 \%$ and a peak in levels of 226.29 over 100 bases at January 2000 (Demmler, 2017). During this period from January 2002 to January 2006 housing mortgagers spent time and effort covering mortgages fees, increasing the presence of sunk costs in house owners.

\section{Sunk Costs Fallacy in Subprime Bubble}


Figure 1. Bubble development according with Composite-10 CSXR housing index.

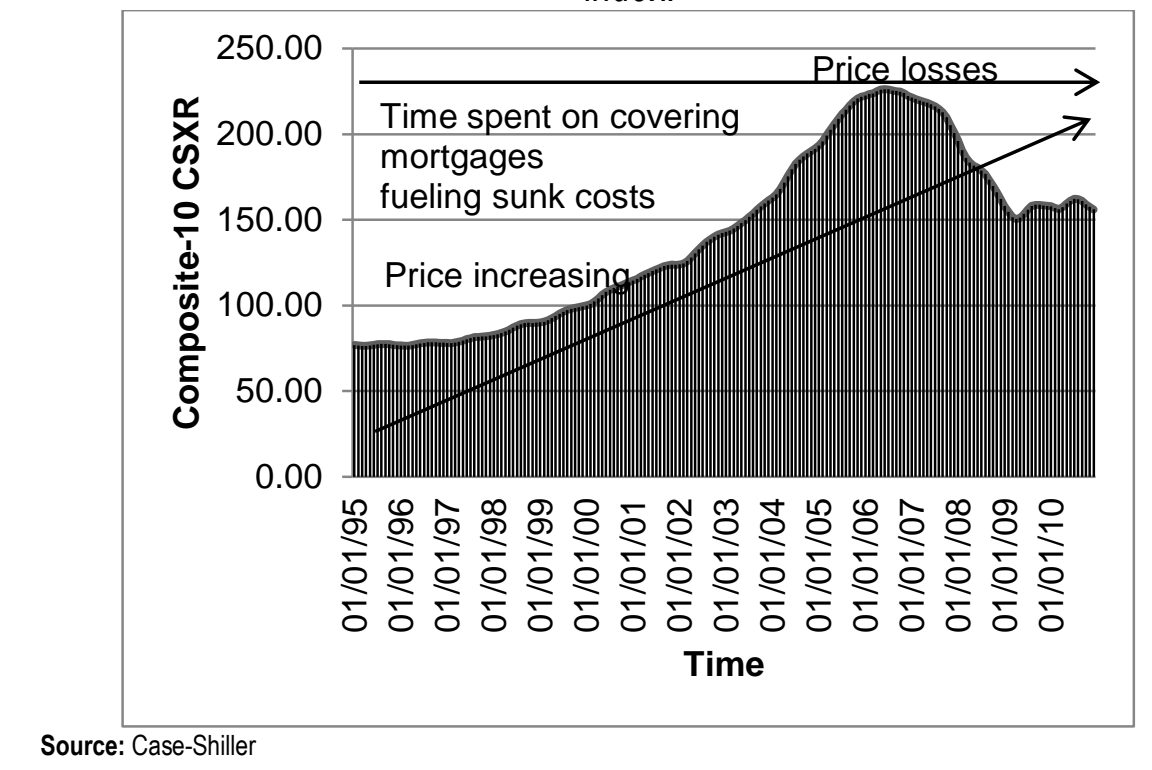

Although, (Friedman, Pommerenke, Lukose, Milam, \& Huberman (2007) investigation consider that sunk cost fallacy is not always evident as is supposed, and people rationalize decisions as long as they have experienced favorable or unfavorable situations. In addition, the research of Ratnadiwakara \& Yerramilli (2017), finds the role of sunk costs in selling housing process, identifying general implications of payments and taxes in selling disposition, demonstrating that sunk cost fallacy is stronger as long as mortgage fee is higher, specifically when they experienced an important loss on the sale price, affecting this condition to the housing market.

In support of this dissertation, the housing price reversal presented in Figure 1. is a revelator because it enhances the importance of behavior according to other findings (Ratnadiwakara \& Yerramilli, 2017), even when their research is not related to bubble formation and its implications. It is important to clarify that the relevance of the past due mortgages created the main problem of the bubble in-stock pricing. If mortgages were paid as it was planned to be, stock pricing would not fall as happened due to the correction of sunk costs fallacy, though there are many more reasons that made this

\section{Velázquez Juárez, E.}


bubble formation. It is suggested, that sunk cost fallacy has an important role to consider, because the existence of risk mitigation, as it would be mortgage transfer. It can be an option to reduce effects of sunk cost affectation in housing market, reducing reasons -additional to legal and ethical implications- to the formation of asset bubbles for further researches.

The implications of the subprime bubble are several, if it is considered mortgagers conditions, the implication was housing foreclosures due to credit default. The U.S. implied severe financial losses in banks, which reflected their losses around the world as a result of a liquidity and capital crisis, because of fails of commercial banks, investment banks, mortgage lenders and insurance companies (Aoki \& Nikolov, 2015). After the bubble, the main changes experienced were the rescue and takeover of the U.S. investment banks and the bankruptcy of many others. Additionally, other mortgager institutions were taken for the U.S. government and the banking system required liquidity injections by the central banks to improve the situations. As a consequence of this financial disruption, ethics in banks and rating institutions were put in doubt and they were forced to get stricter requirements for credit policy and rating financial instruments (Schwartz, 2011).

As a response to the financial bubble, the Federal Reserve in association with central banks around the world took measures to address the crisis, those were: Lowered the federal funds rate, opened market operations to ensure banks remain liquid, facilitated FED to lend directly to the bank and non-bank institutions (Brunnermeier \& Schnabel, 2015).

Considering legal implications, some regulatory proposals were put into consideration, as they are: expand the Federal Deposit Insurance Corporation bank resolution mechanism to include non-bank financial institutions; ensure that a firm is allowed to fail in an orderly way and not be rescued; require stronger capital and liquidity positions for financial firms and related regulatory authority. There came an important enforcement action and legal processes resulting from the Subprime bubble crisis, they were investigations looking into fraud by mortgage financing from diverse financing companies and insurer American International Group (Brunnermeier \& Schnabel, 2015). 


\section{Discussion}

As synthesis, it has been reviewed that the subprime bubble is considered as one of the most important catastrophic events in global financial markets history. This involves uncountable reasons that contributed to its creation, development, and crash. In this paper has recovered the main aspects of the bubble and it is considered one extra characteristic in behavioral finances, known as the sunk cost fallacy, and its described from the housing mortgagers, rather than the stock investors as the common literature review suggests.

The main ideas recollected through this paper regarding Subprime Bubble are that even though the financial markets have a regulation frame, it still was insufficient for that specific moment. Global economy experienced several troubles that should have been considered during innovation events, which usually disrupt pre-existing legal frames, putting into a new and complex scenario to the whole financial system. In this particular case, the innovation stood in the creation of risk transferring -credit risk- from the mortgagers to the stock investors into three different segments of securities. It became hard to control as long as banks did not take care about the credit applicants and their worthiness, in this paper is suggests that credit applicants also experiment sentiment along their investments, and they stood as much as they can paying their mortgage, even when its financial cost is each time higher, driven by their own sunk cost fallacy. Subprime bubble increased as the past due to mortgages also reached and excessive amount, contributing to the stock price fall.

The main consequences that the bubble brought with it were severe liquidity and capital crisis around the world; also house owners were exposed to critical foreclosures ending with their past and sunk efforts and dreams. As a transformation after the crisis, it brought for the U.S. diverse legal mechanisms, as they were lowering FED's rates and guarantee liquidity for remaining financial institutions, controlling stability and stronger capital positions for financial and non-financial institutions that may work as lenders (Brunnermeier \& Schnabel, 2015; Demmler, 2017; Foote \& Willen, 2016b; Markham, 2015; Talbi \& Halima, 2019).

For this reason, this article puts into consideration more complex perspectives to develop new researches that consider including behavioral

\section{Velázquez Juárez, E.}


perspective into finances, associated not only to investor sentiment but other participant's behavior. In this sense, sunk cost fallacy is also present in several conditions related with finance such as financial markets, stock investment decisions and decision-making in personal finances.

\section{References}

Agarwal, S., Green, R. K., Rosenblatt, E., \& Yao, V. (2015). Collateral pledge, sunk-cost fallacy and mortgage default. Journal of Financial Intermediation, 24(4), 636-652. https://doi.org/10.1016/j.jfi.2014.10.001

Aoki, K., \& Nikolov, K. (2015). Bubbles, banks and financial stability. Journal of Monetary Economics, 74, 33-51.

Augenblick, N. (2016). The Sunk-Cost Fallacy in Penny Auctions. The Review of Economic Studies, 83(1), 58-86. https://doi.org/10.1093/restud/rdv037

Bernal, C. A. (2010). Metodología de la investigación. 322.

Brueckner, J., Calem, P., \& Nakamura, L. (2011). Subprime Mortgages and the Housing Bubble. Recuperado

de https://www.anderson.ucla.edu/Documents/areas/fac/finance/subprime\%20(2).pdf

Brunnermeier, M. K., \& Schnabel, I. (2015). Bubbles and Central Banks: Historical Perspectives (SSRN Scholarly Paper N. ${ }^{\circ}$ ID 2592370). Recuperado de Social Science Research Network website: https://papers.ssrn.com/abstract $=2592370$

Cazau, P. (2006). INTRODUCCIÓN A LA INVESTIGACIÓN EN CIENCIAS SOCIALES. 194.

Demmler, M. (2017). Irrationality of Asset Price Bubbles (Primera). Pearson Educación.

Doody, R. (2017). The Sunk Cost'Fallacy'is Not a Fallacy.

Foote, C. L., \& Willen, P. S. (2016a). Subprime mortgage crisis, the. En Banking Crises (pp. 324-336). Springer.

Foote, C. L., \& Willen, P. S. (2016b). Subprime mortgage crisis, the. En Banking Crises (pp. 324-336). Springer.

Friedman, D., Pommerenke, K., Lukose, R., Milam, G., \& Huberman, B. A. (2007). Searching for the sunk cost fallacy. Experimental Economics, 10(1), 79-104. https://doi.org/10.1007/s10683-006-9134-0

Galeano, E. (2012). Estrategias de Investigación cualitativa. El giro de la mirada. Medellín: La carreta editores.

Haita-Falah, C. (2017). Sunk-cost fallacy and cognitive ability in individual decision-making. Journal of Economic Psychology, 58, 44-59. https://doi.org/10.1016/j.joep.2016.12.001

Krämer, A. (2017). Demystifying the "Sunk Cost Fallacy»: When Considering Fixed Cost in Decision-Making is Reasonable. https://doi.org/10.17722/jorm.v7i1.167

Markham, J. W. (2015). A Financial History of the United States: From Enron-Era Scandals to the Subprime Crisis (2004-2006); From the Subprime Crisis to the Great Recession (2006-2009). Routledge.

Muñoz, C. (2015). Metodología de la investigación (Primera). México: Oxford.

\section{Sunk Costs Fallacy in Subprime Bubble}


Namouri, H., Jawadi, F., Ftiti, Z., \& Hachicha, N. (2018). Threshold effect in the relationship between investor sentiment and stock market returns: A PSTR specification. Applied Economics, 50(5), 559-573.

Schwartz, H. M. (2011). Subprime nation: American power, global capital, and the housing bubble. Cornell University Press.

Shiller, R. J. (2012). The subprime solution: How today's global financial crisis happened, and what to do about it. Princeton University Press.

Talbi, M., \& Halima, A. B. (2019). Global Contagion of Investor Sentiment during the US Subprime Crisis: The Case of the USA and the Region of Latin America. International Journal of Economics and Financial Issues, 9(3), 163.

Velázquez Juárez, E. 